\title{
Body composition among long distance runners
}

\author{
(iD) Joana Rosado $\mathbf{1 , 2}$ \\ (iD) João P. Duarte 3,4 \\ (1) Paulo Sousa-e-Silva $a^{3,4,5}$ \\ (iD) Daniela C. Costa $3,4,6$ \\ (iD) Diogo V. Martinho $0^{3,4,7}$ \\ João Valente-dos-Santos ${ }^{4,8}$ \\ (iD) Luís M. Rama ${ }^{3,4}$ \\ DÓscar M. Tavares ${ }^{1}$ \\ (iD) Jorge Conde \\ D) Joaquim Castanheira ${ }^{1}$ \\ Dui Soles-Gonçalves ${ }^{1}$ \\ (iD) Daniel Courteix ${ }^{9}$ \\ Manuel J. Coelho-e-Silva ${ }^{3,4}$
}

1. Coimbra Health School, Polytechnic Institute of Coimbra, Coimbra, Portugal. 2. Faculty of Sport, University of Porto, Porto, Portugal. 3. Faculty of Sport Sciences and Physical Education, University of Coimbra, Coimbra, Portugal. 4. CIDAF (uid/dtp/04213/2019), University of Coimbra, Coimbra, Portugal. 5. Portuguese Foundation for Science and Technology (SFRH/BD/138608/2018), Lisbon, Portugal. 6. Portuguese Foundation for Science and Technology (SFRH/BD/136193/2018), Lisbon, Portugal. 7. Portuguese Foundation for Science and Technology (SFRH/BD/121441/2016), Lisbon, Portugal. 8. Faculty of Physical Education and Sport, Lusofona University of Humanities and Technology, Lisbon, Portugal. 9. Laboratory of Metabolic Adaptations to Exercise in Physiological and Pathological conditions (AME2P, EA3533), University of Clermont Auvergne, Clermont-Ferrand, France.

http://dx.doi.org/10.1590/1806-9282.66.2.180

\section{SUMMARY}

OBJECTIVE: The current study aimed to examine the body composition of adult male ultra-trail runners (UTR) according to their level of participation (regional UTR-R, vs. national UTR-N).

METHODS: The sample was composed of 44 adult male UTR (aged 36.5 7.2 years; UTR-R: $n=25$; UTR-N: $n=19$ ). Body composition was assessed by air displacement plethysmography, bioelectrical impedance, and dual-energy X-ray absorptiometry. In addition, the Food Frequency Questionnaire (FFQ) was applied. A comparison between the groups was performed using independent samples t-test.

RESULTS: Significant differences between groups contrasting in the competitive level were found for chronological age (in years; UTR-

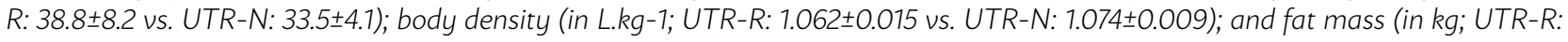
$12.7 \pm 6.8$ vs. UTR-N: $7.6 \pm 2.7$ ).

CONCLUSION: UTR-N were younger, presented higher values for body density, and had less fat mass, although no significant differences were found for fat-free mass. The current study evidenced the profile of long-distance runners and the need for weight management programs to regulate body composition.

KEYWORDS: Plethysmography. Electric impedance. Absorptiometry, photon.

DATE OF SUBMISSION: 10-Aug-2019

DATE OF ACCEPTANCE: 01-Sep-2019

CORRESPONDING AUTHOR: Manuel Coelho-e-Silva

Estádio Universitário de Coimbra, Pavilhão III, Coimbra - 3040-156

E-mail: mjcesilva@hotmail.com 


\section{INTRODUCTION}

Ultra-trail running is gaining social popularity, and the number of participants is continuously increasing with competitions ranging between $42-99 \mathrm{~km}$. The sport comprises intermittent intensities of effort (i.e., walking and running in a broad spectrum of positive and negative slopes) at different contexts (type of ground, wind) ${ }^{1}$. As for many other sports, body composition has been considered a determinant factor, particularly because it requires the displacement of the whole body corresponding to inertia for running, cycling, and swimming ${ }^{2,3}$. A substantial inter-variability in morphology and body composition has been noted in the literature ${ }^{4}$. Previous studies ${ }^{5,6}$ compared $^{2}$ competitive runners with recreational runners, or runners with athletes from other sports. The literature consistently suggests that long-distance runners are characterized by small body size, including body mass and its components ${ }^{7,8}$. Fat mass corresponds to the biological form of energy storage, and a minimum level is recommended for athletes of long events ${ }^{9}$. The optimal combination of body size, muscularity, and fat should be viewed as sport-specific.

Cross-sectional studies on long-distance runners corroborated the negative role of fat mass (FM) in running performance $\mathrm{e}^{1,4}$. Although the two-component model has been reported as the most common option to examine body composition, it should be recognized that fat-free mass (FFM) is constituted of several other components, such as water, protein, mineral, and gly$\operatorname{cogen}^{10}$. An accurate assessment of body composition requires concurrent technologies to inform about fat mass, lean body mass, bone mineral content (BMC), body water (total, intra-cellular, extra-cellular) for the whole body and regions of interests (trunk, appendicular). Other models, termed 3-compartment and 4-compartment, allow a better estimation of body composition, although assumptions are required ${ }^{10}$. Information obtained from concurrent technologies (bioimpedance analysis, air displacement plethysmography, dual-energy x-ray absorptiometry, respectively BIA, ADP, DXA) is often combined to produce more robust estimates ${ }^{3,11,12}$.

Prolonged episodes of exercise require specific demands of nutrients and hydration. The diet, in parallel to training, has a relevant impact on body composition and the ability to overcome fatigue ${ }^{13-15}$. By inference, the contribution of carbohydrate, protein, fat intake, and micronutrients should be considered as part of the training of long-distance runners. It is consensual that the ingestion of carbohydrates before and during prolonged exercises would delay fatigue, saving the hepatic and muscular glycogen by providing glucose directly to the active muscles. More recently, recommendations have emerged for improving performance by including lipid supplementation through the ingestion of medium-chain triglycerides during exercise or a high-fat diet during the days before competition $^{15}$. In the meantime, although body composition and diet are often recognized as crucial for long-distance runners, the literature devoted to the concurrent assessment of body composition in long-distance runners is still lacking, particularly at competitive levels. The present study aimed to examine the body composition of male adult ultra-trail runners (UTR) and, additionally, to compare participants by level of participation (regional versus national). Given the negative contribution of FM in long-distance anti-gravitational efforts, it was hypothesized that better athletes are characterized by lower levels of fat mass with fat-free mass adequately kept.

\section{METHODS}

\section{Procedures and sample}

The procedures of the current study fit the guidelines for research ${ }^{16}$. The project was previously approved by two Ethics Committees (University of Coimbra: CE/FCDEF-UC/00102014; University of Porto: CEFADE 17.2017). Participants were recruited by convenience. The sample corresponds to male runners who participated in official competitions in the Coimbra area and, after being contacted, demonstrated availability to visit the Coimbra University Stadium 2-4 weeks after the event for data collection. Their geographic origins covered seven districts. Participants individually signed an informed consent form prior to data collection. All measurements were obtained by experienced technicians. The sample was composed of 44 adult male runners. The inclusion criteria were: experience in UTR for two or more years; participation in regional or national competitions organized by the Portuguese Trail Running Association; having concluded a minimum of five competitions in the previous season. Additionally, the exclusion criterion was the presence of musculoskeletal injury, affecting training time during the previous two months. Runners were divided according to their level of practice: regional ultra trail runners $v s$. national ultra trail runners, respectively (UTR-R and UTR-N). The regional level 
included runners without objectives for the nationwide ranking, while the national group included those qualified for the nation-wide championship in addition to participation in international events during the past two seasons. The later athletes are systematically exposed to individual coaching with prescriptions for training, diet, and recovering methods.

\section{Anthropometry}

Stature was measured with a portable stadiometer (Harpenden stadiometer, model 98.603, Holtain, Crosswell, UK). Measurements were performed to $0.1 \mathrm{~cm}$ accuracy. Body mass was quantified using a portable scale (SECA balance, model 770, Hanover, MD, USA) with a precision of $0.1 \mathrm{~kg}$.

\section{Air-displaced plethysmography (ADP)}

Body volume was assessed by air-displaced plethysmography (Bod Pod Body Composition System, model Bod Pod 2006, Life Measurement Instruments, Concord, CA, USA). The instrument was previously calibrated with a 50.255L cylinder following the procedures issued by the manufacturer. Participants were using lycra underwear and a swimming cap. Each individual repeated the test at least two times until a maximum variation of $150 \mathrm{~mL}$ was obtained. The whole-body volume was adjusted for estimated thoracic gas volume. Afterward, body density was calculated by dividing the body mass $(\mathrm{kg})$ by the body volume $(\mathrm{L})$. The percentage of fat mass was estimated from body density using the equation proposed for normal weight adults ${ }^{17}$.

\section{Bioelectrical impedance analysis (BIA)}

Total body water was measured using an electric bioimpedance analyzer (Akern, model BIA101, Akern Srl, Florence, Italy) and the specific software recommended by the manufacturer (Bodygram - version 1.3 Akern Srl, Florence, Italy). Participants were lying in the dorsal position, and electrodes were placed on the hand and feet, passing an electric current with very low intensity $(800 \mu \mathrm{A})$ and with a constant frequency (50kHz).

\section{Dual-energy $\mathrm{x}$-ray absorptiometry (DXA)}

DXA was used to estimate the body composition of the whole body and lower limbs. The above-mentioned data were obtained using LUNAR (Lunar DPX-MD+, Software: enCORE version 4.00.145, GE Lunar Corporation, Madison, WI, USA) with participants placed on the table of the equipment in dorsal decubitus position following the recommendations of the manufacturer. Data acquisition and analysis were performed by an experienced technician in a certified laboratory.

\section{Food frequency questionnaire (FFQ)}

A self-administered questionnaire (FFQ) was applied to obtain seasonality, frequency, and portion volume for 86 food items. The questionnaire was adapted for Portuguese ${ }^{18}$ and informed about the habitual consumption using a scale of nine options (from "never or less than once a month" to " 6 or more times per day"). The final values summarize the number of calories and macronutrients.

\section{Analyses}

Descriptive statistic was calculated for the total sample (range, mean, standard error of the mean, 95\% confidence interval of the mean and standard deviation). Normality was examined. For the comparison between the groups, an independent samples t-test was used. The magnitude of the effects was interpreted as follows ${ }^{19}$ : $<0.20$ (trivial); 0.20 to 0.59 (small); 0.60 to 1.19 (moderate); 1.20 to 1.99 (large); 2.00 to 3.99 (very large); $\geq 4.00$ (extremely large). The significance level was established at $5 \%$. Statistical analyses were performed using the Statistical Package for the Social Sciences - SPSS, version 25 for Windows (SPSS Inc., IBM Company, Armonk, NY, USA).

\section{RESULTS}

Table 1 summarizes descriptive statistics for the total sample. Comparisons of UTR according to the competitive level are presented in Table 2. UTR-N were younger $(\mathrm{t}=2.808 ; \mathrm{p}<0.01 ; \mathrm{d}=0.80)$, with higher values for body density $(\mathrm{t}=-3.369 ; \mathrm{p}<0.01 ; \mathrm{d}=-0.96)$, lower values for body volume $(\mathrm{t}=2.135 ; \mathrm{p}<0.05 ; \mathrm{d}=0.67)$ and, consequently, for fat mass $(\mathrm{t}=3.425 ; \mathrm{p}<0.01$; $\mathrm{d}=$ 0.96). No differences were found for fat-free mass by ADP, total body water by BIA, or lean soft tissue from DXA. For all the above-mentioned significant differences, the magnitude of the differences was moderate $(0.6<\mathrm{d}<1.2)$. Fat mass (in kg) was similar by two concurrent protocols, as shown in Figure 1.

\section{DISCUSSION}

The current study examined inter-variability according to competitive level among male Portuguese 
TABLE 1. DESCRIPTIVE STATISTICS FOR THE TOTAL SAMPLE OF ADULT MALE LONG-DISTANCE RUNNERS (N=44) AND NORMALITY TEST FOR CHRONOLOGICAL AGE, TRAINING EXPERIENCE, BODY SIZE GIVEN BY STATURE AND BODY MASS, AND INDICATORS OF BODY COMPOSITION.

\begin{tabular}{|c|c|c|c|c|c|c|c|c|c|}
\hline \multirow{2}{*}{ Variable } & \multirow{2}{*}{ units } & \multicolumn{2}{|l|}{ Range } & \multicolumn{3}{|l|}{ Mean } & \multirow{2}{*}{$\begin{array}{l}\text { Standard } \\
\text { deviation }\end{array}$} & \multicolumn{2}{|l|}{ Normality } \\
\hline & & Minimum & Maximum & Value & Standard error & $(95 \% \mathrm{Cl})$ & & $\mathrm{K}-\mathrm{S}$ value & $\mathrm{p}$ \\
\hline Chronological age & years & 23.3 & 53.2 & 36.5 & 1.1 & (34.3 to 38.7) & 7.2 & 0.081 & 0.20 \\
\hline Training experience & years & 2 & 17 & 4.0 & 0.4 & (3.10 to 4.8$)$ & 2.8 & 0.314 & $<0.01$ \\
\hline Stature & $\mathrm{cm}$ & 161.8 & 189.7 & 174.4 & 1.0 & (172.3 to 176.5) & 6.9 & 0.109 & 0.20 \\
\hline Body mass & $\mathrm{kg}$ & 58.5 & 100.5 & 73.0 & 1.5 & (70.1 to 76.0 ) & 9.6 & 0.142 & 0.03 \\
\hline \multicolumn{10}{|l|}{ ADP } \\
\hline Body volume & $\mathrm{L}$ & 54.382 & 98.103 & 68.508 & 1.455 & (65.574 to 71.441$)$ & 9.649 & 0.137 & 0.04 \\
\hline Body density & $\mathrm{kg} / \mathrm{L}$ & 1.025 & 1.088 & 1.067 & 0.002 & (1.063 to 1.071$)$ & 0.014 & 0.232 & $<0.01$ \\
\hline \multirow[t]{2}{*}{ Fat mass } & $\%$ & 4.8 & 33.2 & 13.9 & 0.9 & (12.0 to 15.8 ) & 6.2 & 0.229 & $<0.01$ \\
\hline & $\mathrm{kg}$ & 3.0 & 33.4 & 10.5 & 0.9 & $(8.6$ to 12.3$))$ & 6.0 & 0.186 & $<0.01$ \\
\hline Fat free mass & $\mathrm{kg}$ & 51.5 & 77.3 & 62.6 & 1.0 & (60.5 to 64.7 ) & 6.9 & 0.093 & 0.20 \\
\hline \multicolumn{10}{|l|}{$\mathrm{BIA}$} \\
\hline Total body water & $\mathrm{L}$ & 34.8 & 58.6 & 45.0 & 0.8 & (43.4 to 46.6 ) & 5.4 & 0.092 & 0.20 \\
\hline \multicolumn{10}{|l|}{ DXA - whole body } \\
\hline $\mathrm{BMC}$ & g & 2413 & 4128 & 3219 & 68 & (3082 to 3356) & 451 & 0.095 & 0.20 \\
\hline BMD & $\mathrm{g} / \mathrm{cm} 2$ & 1.103 & 1.450 & 1.268 & 0.014 & (1.234 to 1.296) & 0.093 & 0.098 & 0.20 \\
\hline Fat tissue & $\mathrm{kg}$ & 4.2 & 33.6 & 10.8 & 0.9 & (8.9 to 12.6 ) & 6.2 & 0.172 & $<0.01$ \\
\hline Lean soft tissue & $\mathrm{kg}$ & 48.3 & 72.3 & 58.6 & 0.9 & (56.8 to 60.4) & 5.9 & 0.102 & 0.20 \\
\hline \multicolumn{10}{|l|}{ DXA - lower limbs } \\
\hline BMC & g & 932 & 1635 & 1250 & 26 & (1198 to 1303) & 174 & 0.112 & 0.20 \\
\hline BMD & $\mathrm{g} / \mathrm{cm} 2$ & 1.172 & 1.620 & 1.423 & 0.017 & (1.388 to 1.458$)$ & 0.114 & 0.098 & 0.20 \\
\hline Fat tissue & $\mathrm{kg}$ & 1.2 & 9.5 & 3.2 & 0.3 & (2.7 to 3.8$)$ & 1.7 & 0.174 & $<0.01$ \\
\hline Lean soft tissue & $\mathrm{kg}$ & 16.9 & 25.1 & 20.6 & 0.3 & (20.0 to 21.3) & 2.2 & 0.098 & 0.20 \\
\hline
\end{tabular}

ADP (air displacement plethysmography); BIA (bioelectrical impedance analysis); DXA (dual-energy X-ray absorptiometry); BMC (bone mineral content); BMD (bone mineral density); $95 \% \mathrm{Cl}$ (95\% confidence interval); K-S (Kolmogorov-Smirnov test); p (significance level)

ultra-trail runners characterized by low levels of fat mass. In addition, regional and national groups differed in body volume and, consequently, in body density with implications in the mean values of estimated fat mass. Finally, although concurrent methods for assessing body composition did not fully agree, both air displacement plethysmography and DXA technology evidenced that national runners have lower levels of fat mass.

The chronological age of the sample in the current study was similar to that calculated in other studies dealing with long-distance runners ${ }^{5}$. The results of the current study suggested that stature and body mass are similar to data obtained from long-distance athletes, such as marathon runners and 24-hour ultra-marathon runners ${ }^{7}$. The mean value of body fat percentage of the present study was substantially lower than $161-\mathrm{km}$ ultra marathoners ${ }^{20}$ and $65-\mathrm{km}$ mountain ultra-marathon ${ }^{4}$, despite the substantial inter-individual variability for fatness. Runners contrasting in competitive level demonstrated distinct values for body composition. As expected, UTR-N exhibited lower levels of fat mass, which was reasonably reported by different protocols: DXA and air displacement plethysmography, suggesting both as valid options for weight management.

Estimates for body composition using ADP, BIA, and DXA were within normal variation for athletes of similar sport events ${ }^{21}$. Both groups of UTR presented the same amount of fat-free tissue, but UTR-R significantly carried lower values of body density (higher amount of fat). It is intuitively established that if a long-distance runner, such as a marathon runner, exceeds $15 \%$ of FM, he will probably perform at a lower running pace ${ }^{9}$. Another important aspect of body composition refers to bone tissue (content, density). UTR are exposed to repetitive mechanical impacts believed to be positively associated with bone health parameters, although in the current study, the differences between the groups for BMC (whole body and lower limbs) appeared negligible (see Figure 1). This suggests that the main benefits are probably observed between non-athletes and the trivial to small variability among athletes could be explained by the intensity 
TABLE 2. MEAN AND STANDARD DEVIATION BY COMPETITIVE GROUP (REGIONAL VS NATIONAL) AND COMPARISONS BETWEEN THE GROUPS, INCLUDING MAGNITUDE EFFECTS OF THE MEAN DIFFERENCES ON CHRONOLOGICAL AGE, TRAINING EXPERIENCE, BODY SIZE GIVEN BY STATURE AND BODY MASS, AND INDICATORS OF BODY COMPOSITION PLUS DIET NUTRIENTS (OBTAINED FROM FOOD FREQUENCY QUESTIONNAIRE).

\begin{tabular}{|c|c|c|c|c|c|c|c|c|}
\hline \multirow{3}{*}{\multicolumn{2}{|c|}{ Yi: Dependent variable }} & \multicolumn{2}{|c|}{$\mathrm{X}$ : Independent variable } & \multicolumn{5}{|l|}{ Comparison } \\
\hline & & \multirow{3}{*}{$\begin{array}{l}\begin{array}{l}\text { Regional } \\
(n=25)\end{array} \\
38.8 \pm 8.2 \\
\end{array}$} & \multirow{3}{*}{\begin{tabular}{|l|}
$\begin{array}{l}\text { National } \\
(n=19)\end{array}$ \\
$33.5 \pm 4.1$ \\
\end{tabular}} & \multirow{3}{*}{$\begin{array}{l}\text { Difference of means } \\
(95 \% \mathrm{Cl}) \\
5.3(1.5 \text { to } 9.1) \\
\end{array}$} & \multicolumn{2}{|c|}{ t-student } & \multicolumn{2}{|c|}{ Magnitude of effects } \\
\hline & & & & & \multirow{2}{*}{$\begin{array}{l}\mathrm{t} \text {-value } \\
2.808 \\
\end{array}$} & \multirow{2}{*}{$\begin{array}{l}\mathrm{p} \\
<0.01\end{array}$} & \multirow{2}{*}{$\begin{array}{l}d \\
0.80\end{array}$} & \multirow{2}{*}{$\begin{array}{l}\text { (qualitative) } \\
\text { (moderate) }\end{array}$} \\
\hline Chronological age & years & & & & & & & \\
\hline Training experience & years & $3.9 \pm 3.0$ & $4.1 \pm 2.6$ & $0.2(-1.9$ to 1.6$)$ & -0.199 & 0.84 & -0.07 & (trivial) \\
\hline Stature & $\mathrm{cm}$ & $174.2 \pm 6.5$ & $174.7 \pm 7.4$ & $0.5(-4.8$ to 3.7$)$ & -0.243 & 0.81 & -0.03 & (trivial) \\
\hline Body mass & kg & $75.4 \pm 10.5$ & $69.9 \pm 7.6$ & $5.5(-0.2$ to 11.2$)$ & 1.931 & 0.06 & 0.60 & (moderate) \\
\hline ADP: Body volume & $L$ & $71.110 \pm 10.611$ & $65.085 \pm 7.106$ & 6.025 (0.330 to 11.721) & 2.135 & 0.04 & 0.67 & (moderate) \\
\hline ADP: Body density & $\mathrm{L} / \mathrm{kg}$ & $1.062 \pm 0.015$ & $1.074 \pm 0.009$ & $-0.012(-0.020$ to -0.005$)$ & -3.369 & $<0.01$ & -0.96 & (moderate) \\
\hline \multirow[t]{2}{*}{ ADP: Fat mass } & $\%$ & $16.2 \pm 6.8$ & $10.8 \pm 3.7$ & $5.4(2.2$ to 8.6$)$ & 3.388 & $<0.01$ & 0.97 & (moderate) \\
\hline & kg & $12.7 \pm 6.8$ & $7.6 \pm 2.7$ & 5.1 (2.1 to 8.1$)$ & 3.425 & $<0.01$ & 0.96 & (moderate) \\
\hline ADP: Fat free mass & kg & $62.8 \pm 6.7$ & $62.3 \pm 7.4$ & $0.4(-3.8$ to 4.7$)$ & 0.210 & 0.84 & 0.07 & (trivial) \\
\hline BIA: Total body water & $\mathrm{L}$ & $46.3 \pm 5.5$ & $43.4 \pm 4.9$ & $3.0(0.3$ to 6.1$)$ & 1.829 & 0.07 & 0.57 & (small) \\
\hline DXA - whole-body:BMC & g & $3196 \pm 435$ & $3250 \pm 482$ & $-54(-336$ to 226$)$ & -0.387 & 0.70 & -0.12 & (trivial) \\
\hline DXA - whole-body:BMD & $\mathrm{g} / \mathrm{cm}^{2}$ & $1.266 \pm 0.096$ & $1.271 \pm 0.092$ & $-0.005(-0.063$ to 0.052$)$ & -0.188 & 0.85 & -0.05 & (trivial) \\
\hline DXA - whole-body:FT & $\mathrm{kg}$ & $13.1 \pm 7.1$ & $7.6 \pm 2.4$ & 5.5 (2.4 to 8.6$)$ & 3.648 & $<0.01$ & 1.01 & (moderate) \\
\hline DXA - whole-body:LST & kg & $58.5 \pm 6.0$ & $58.7 \pm 6.0$ & $-0.2(-3.9$ to 3.5$)$ & -0.112 & 0.91 & -0.03 & (trivial) \\
\hline DXA - lower limbs: BMC & g & $1246 \pm 176$ & $1257 \pm 176$ & $-11(-119$ to 97$)$ & -0.206 & 0.84 & -0.06 & (trivial) \\
\hline DXA - lower limbs: BMD & $\mathrm{g} / \mathrm{cm}^{2}$ & $1.405 \pm 0.114$ & $1.446 \pm 0.115$ & $-0.040(-0.110$ to 0.030$)$ & -1.158 & 0.25 & -0.37 & (small) \\
\hline DXA - lower limbs: FT & $\mathrm{kg}$ & $3.9 \pm 1.9$ & $2.4 \pm 0.8$ & 1.6 (0.6 to 2.5) & 3.686 & $<0.01$ & 1.04 & (moderate) \\
\hline DXA - lower limbs: LST & $\mathrm{kg}$ & $20.7 \pm 2.4$ & $20.6 \pm 2.1$ & $0.2(-1.2$ to 1.5$)$ & 0.243 & 0.81 & 0.04 & (trivial) \\
\hline FFQ: Calories & kcal & $2629 \pm 856$ & $2323 \pm 755$ & 306 (194 to 806) & 1.234 & 0.22 & 0.38 & (small) \\
\hline FFQ: Proteins & $\%$ & $21.2 \pm 4.8$ & $21.7 \pm 3.5$ & $-0.5(-3.1$ to 2.1$)$ & -0.404 & 0.69 & -0.12 & (trivial) \\
\hline FFQ: Carbohydrates & $\%$ & $46.4 \pm 7.6$ & $49.0 \pm 8.7$ & $-2.5(-7.5$ to 2.5$)$ & -1.016 & 0.32 & -0.33 & (small) \\
\hline FFQ: Total fat & $\%$ & $33.7 \pm 4.9$ & $30.8 \pm 5.5$ & $2.8(-0.4$ to 6.0$)$ & 1.796 & 0.08 & 0.57 & (small) \\
\hline FFQ: Saturated fat & $\%$ & $8.8 \pm 1.9$ & $8.5 \pm 2.8$ & $0.3(-1.1$ to 1.7$)$ & 0.448 & 0.66 & 0.13 & (trivial) \\
\hline FFQ: Monounsaturated fat & $\%$ & $15.0 \pm 3.3$ & $13.3 \pm 3.0$ & $1.7(-0.2$ to 3.6$)$ & 1.762 & 0.09 & 0.55 & (small) \\
\hline FFQ: Polyunsaturated fat & $\%$ & $5.4 \pm 0.9$ & $4.6 \pm 1.2$ & $0.9(0.2$ to 1.5$)$ & 2.680 & $<0.01$ & 0.79 & (moderate) \\
\hline FFQ: Cholesterol & mg & $528 \pm 167$ & $441 \pm 143$ & $88(-8$ to 184$)$ & 1.841 & 0.07 & 0.57 & (small) \\
\hline FFQ: Fibres & g & $37.0 \pm 16.6$ & $56.5 \pm 97.8$ & $-19.5(-59.6$ to 20.6$)$ & 0.981 & 0.33 & -0.31 & (small) \\
\hline FFQ: Ethanol & g & $8.9 \pm 6.3$ & $8.8 \pm 8.8$ & $0.1(-4.5$ to 6.5$)$ & 0.040 & 0.97 & 0.01 & (trivial) \\
\hline FFQ: calcium & $\mathrm{mg}$ & $1149 \pm 562$ & $1110 \pm 642$ & $39(-328$ to 406$)$ & 0.215 & 0.83 & 0.07 & (trivial) \\
\hline
\end{tabular}

ADP (air displacement plethysmography); BIA (bioelectrical impedance analysis); DXA (dual energy X-ray absorptiometry); BMC (bone mineral content); BMD (bone mineral density); FT (fat tissue); LST (lean soft tissue); FFQ (food frequency questionnaire); $95 \% \mathrm{Cl}$ ( $95 \%$ confidence interval); $\mathrm{t}(\mathrm{t}$-student test value); $\mathrm{p}$ (significance); $\mathrm{d}$ (d-Cohen value).

of their participation. However, low values of bone mineral density were reported among long-distance runners $^{22}$, which may be a consequence of stress, including hormonal changes, overtraining, unbalanced diet, and excessively low levels of fat mass. At an ultra-endurance event, such as an ultra-marathon, the runner could experience an average daily expenditure $>8.600 \mathrm{Kcal}$, and at the end of the 5-day running event, the energetic cost approach $59.079 \mathrm{Kcal}^{15}$. Future studies need to examine the diet of professional and amateur UTR participants by using interviews to understand the complex system of erroneous prescription and intuitive beliefs (including supplements). It is possible that the questionnaire (FFQ) used in the present study does not capture all facts for athletes, an aspect that can be considered a weakness of this study and should be the focus of future studies, probably covering a complete season. However, UTR athletes are supposed to have minimum knowledge about nutrition and hydration ${ }^{15}$. BIA was used in the current study and offered an estimate of total body water. Future studies may consider phase angle as an indicator of tissue integrity in relation to performance and fatigue.

The limitations of the present study must be recognized. The sample is not representative of Portuguese ultra-trail runners. Future research also needs to approach the diet using a multi-protocol approach (questionnaire, interview, diary reports). Nevertheless, 


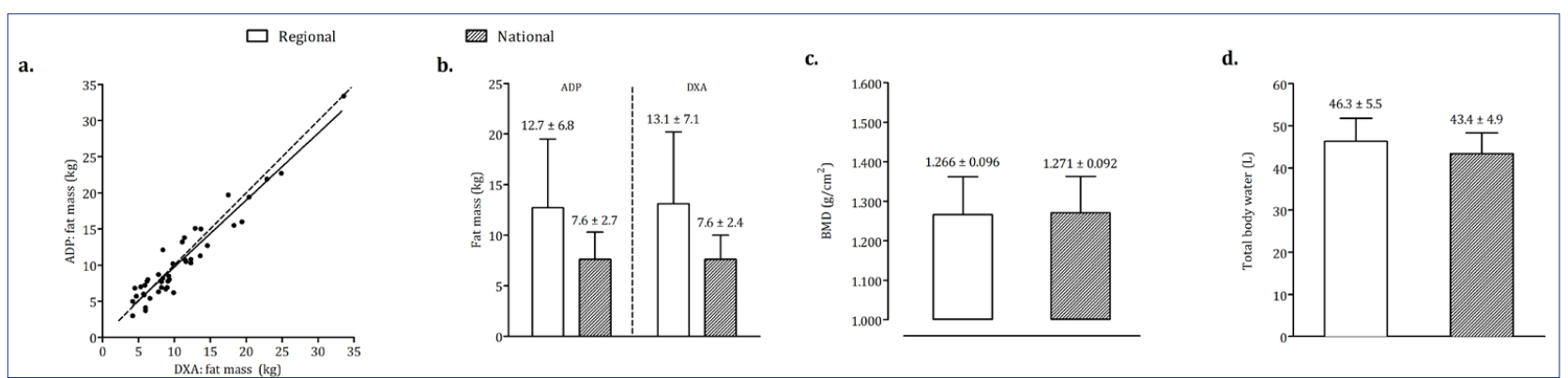

this study has strengths. It combined methodologies to assess body composition and compared the athletes by competitive level. It was possible to profile long-distance runners and to identify the need for adequate weight management, particularly body composition. Altogether, the study shows the need for more specific and effective training supervision, including nutrition.

\section{CONCLUSION}

In summary, ultra-trail runners were characterized by low levels of body fat, demanding accurate regulation of body weight, including adequate maintenance of fat-free mass. These goals require an appropriate diet regarding total calories and nutrients to maintain the integrity of bone and muscle tissues. Bioimpedance is more popularized than absorptiometry and plethysmography and emerged, in the current study, as a reasonable option for assessing body composition.

\section{Conflict of interest}

The authors do not have any conflict of interest.

\section{Acknowledgments}

The authors appreciated the voluntary participation of UTR runners and the collaboration of the Fatima Rosado (Laboratory of Biokinetics, Coimbra University of Coimbra).

\section{RESUMO}

OBJETIVO: O presente estudo objetivou examinar a composição corporal dos corredores de ultra-trail (UTR) e, adicionalmente, comparar dois grupos de acordo com o nível de participação (Regional vs. Nacional, respectivamente UTR-R e UTR-N).

MÉTODOS: A amostra foi composta por 44 corredores adultos masculinos (36,5 7,2 anos de idade; UTR-R: $n=25 ;$ UTR-N: $n=19)$. A composição corporal foi avaliada recorrendo à pletismografia de ar deslocado, bioimpedância elétrica e absorciometria de raios $X$ de dupla energia. Adicionalmente, foi utilizado o Questionário de Frequência Alimentar. A comparação entre grupos foi realizada com base na prova t-student para amostras independentes.

RESULTADOS: Foram encontradas diferenças significativas por nível de competição para as seguintes variáveis dependentes: idade

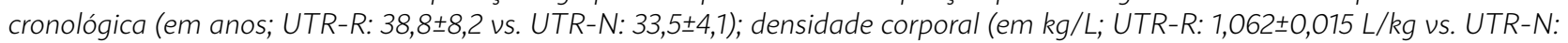

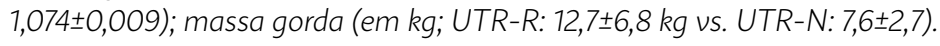

CONCLUSÃO: Os UTR-N tendem a ser mais jovens e apresentam valores superiores de densidade corporal e, consequentemente, valores menores de massa gorda, sendo a massa isenta de gordura semelhante entre os grupos. O presente estudo determinou o perfil dos corredores adultos masculinos de longa distância (ultra-trail), realçando a importância de uma cuidadosa regulação da massa corporal.

PALAVRAS-CHAVE: Pletismografia. Impedância elétrica. Absorciometria de fóton.

\section{REFERENCES}

1. Fornasiero A, Savoldelli A, Fruet D, Boccia G, Pellegrini, B, Schena F. Physiological intensity profile, exercise load and performance predictors of a 65-km mountain ultra-marathon. J Sport Sci. 2018;36(11):1287-95.

2. Ackland TR, Lohman TG, Sundgot-Borgen J, Maughan RJ, Meyer NL, Stewart $A D$, et al. Current status of body composition assessment in sport: review and position statement on behalf of the ad hoc research working group on body composition health and performance, under the auspices of the I.O.C Medical Commission. Sports Med. 2012;42(3):227-49.
3. Malina RM. Body composition in athletes: assessment and estimated fatness. Clin Sports Med. 2007;26(1):37-68.

4. Hoffman MD, Lebus DK, Ganong AC, Casazza GA, Van Loan M. Body composition of 161-km ultramarathoners. Int J Sports Med. 2010;31(2):106-9.

5. Rüst, CA, Knechtle B, Knechtle P, Rosemann T. Comparison of anthropometric and training characteristics between recreational male marathoners and 24-hour ultramarathoners. Open Access J Sports Med. 2012;3:121-9. 
6. Chlíbková D, Alena Ž, Ivana T. Comparison of training, anthropometric, physiological and psychological variables of ultra-endurance cyclists and runners. Proc Soc Behav. 2012;47:1023-7.

7. Knechtle B, Knechtle P, Rosemann T. Similarity of anthropometric measures for male ultra-triathletes and ultra-runners. Percept Mot Skills. 2010;111(3):805-18.

8. Legaz A, Eston R. Changes in performance, skinfold thicknesses, and fat patterning after three years of intense athletic conditioning in high level runners. Br J Sports Med. 2005;39(11):851-6.

9. Tanda $G$, Knechtle B. Marathon performance in relation to body fat percentage and training indices in recreational male runners. Open Access ) Sports Med. 2013;4:141-9.

10. Heymsfield SB, Wang Z, Baumgartner RN, Ross R. Human body composition: advances in models and methods. Annu Rev Nutr. 1997;17:527-58.

11. Tavares Ó, Duarte JP, Costa DC, Sousa-e-Silva P, Martinho D, Lus LGO, et al. Agreement between dual $x$-ray absorptiometers using pencil beam and fan beam: indicators of bone health and whole-body plus appendicular tissue composition in adult athletes. Rev Assoc Med Bras (1992). 2018;64(4):330-8.

12. Silva DR, Ribeiro AS, Pavão FH, Ronque ER, Avelar A, Silva AM, et al. Validity of the methods to assess body fat in children and adolescents using multi-compartment models as the reference method: a systematic review. Rev Assoc Med Bras (1992). 2013;59(5):475-86.

13. Hoffman MD, Stuempfle KJ, Valentino T. Sodium intake during an ultramarathon does not prevent muscle cramping, dehydration, hyponatremia, or nausea. Sports Med Open. 2015;1(1):39.
14. Volek IS, Freidenreich D|, Saenz C, Kunces LI, Creighton BC, Bartley JM et al. Metabolic characteristics of keto-adapted ultra-endurance runners Metabolism. 2016;65(3):100-10.

15. Ferreira AMD, Ribeiro BG, Soares EA. Consumption of carbohydrates and lipids in ultra-endurance exercise performance. Rev Bras Med Esporte. 2017;7(2):67-74

16. Harriss DJ, Atkinson G. Ethical standards in sport and exercise science research: 2016 update. Int | Sports Med. 2015;36(14):1121-4.

17. Siri WE. Body composition from fluid spaces and density: analysis of methods. 1961. Nutrition. 1993;9(5):480-91.

18. Lopes C, Fernandes PV, Cabral S, Barros H. Questionários de frequência alimentar: efeitos da extensão das listas de alimentos na classificação dos inquiridos. Arq Med. 1994;8:291-4.

19. Hopkins WG, Marshall SW, Batterham AM, Hanin J. Progressive statistics for studies in sports medicine and exercise science. Med Sci Sports Exerc. 2009;41(1):3-13.

20. Hoffman MD. Performance trends in 161-km ultramarathons. Int J Sports Med. 2010;31(1):31-7.

21. Agostinete RR, Duarte JP, Valente-dos-Santos |, Coelho-e-Silva MJ, Tavares $\mathrm{OM}$, Conde IM, et al. Bone tissue, blood lipids and inflammatory profiles in adolescent male athletes from sports contrasting in mechanical load. PloS One. 2017;12(6):e0180357.

22. Scofield KL, Hecht $S$. Bone health in endurance athletes: runners, cyclists, and swimmers. Curr Sports Med Rep. 2012;11(6):328-34. 